\title{
Predicting paranoid thoughts in patients with schizophrenia basing on cognitive biases and self-reflection
}

\author{
Fazeleh Heidari $^{1}$, Sajjad Basharpoor ${ }^{2}$, Seifollah Aghajani ${ }^{3}$ \\ 1-PhD Student in Psychology, Department of Psychology, University of Mohaghegh Ardabili, Ardabil, Iran. \\ 2- Professor, Department of Psychology, University of Mohaghegh Ardabili, Ardabil, Iran (Corresponding Author). \\ E-mail: basharpoor_sajjad@uma.ac.ir \\ 3- Associate Professor, Department of Psychology, University of Mohaghegh Ardabili, Ardabil, Iran.
}

Received: 27/09/2019

Accepted: 11/01/2020

\begin{abstract}
Introduction: Paranoid thoughts are common symptom in schizophrenia spectrum disorders. Evidence reveals the role of cognitive factors in these thoughts.

Aim: The present study was conducted in other to predict the paranoid thoughts basing on cognitive biases and self-reflection in patients with schizophrenia.

Method: The correlational method was used in this study. The whole patients with schizophrenia, hospitalized in Isar and Fatemi psychiatric hospitals of Ardabil city in the second half of 2017 year, comprised statistical population of this study. Among this population, One hundred and twenty six patients were selected by purposeful sampling method and participated in this study. Paranoid thoughts questionnaire, Davos Assessment of Cognitive Biases Scale and self-reflection and insight scale were used to gather data. The gathered data were analyzed by Pearson correlation and multivariate regression tests.
\end{abstract}

Results: The correlational results showed that paranoid thoughts are positively related to Jumping to conclusions bias, belief inflexibility bias, attention for threat bias, external attribution bias, social cognition problems, subjective cognitive problems, safety behavior and total score of cognitive biases, but related negatively to insights and total score of self-reflection and insight. The results of regression analysis also showed that $57 \%$ of variance of the paranoid thoughts was explained by cognitive biases, and $36 \%$ of them explained by self-reflection and insight.

Conclusion: The results of this study demonstrated that cognitive biases in thoughts and low self-reflection can be predictive factors for paranoid thoughts in patients with schizophrenia. Thus, the cognitive interventions targeted these variables can be used to improve the paranoid thought in these patients.

Keywords: Thoght, Paranoid, Biases, Cognitive, Schizophrenia

\footnotetext{
How to cite this article : Heidari F, Basharpoor S, Aghajani S. Predicting paranoid thoughts in patients with schizophrenia basing on cognitive biases and self-reflection. Shenakht Journal of Psychology and Psychiatry. 2020; 6 (6): 17-29 .URL: http://shenakht.muk.ac.ir/article-1-659fa.pdf
}

Copyright $(\odot 2018$ the Author (s). Published by Kurdistan University of Medical Sciences. This is an open access article distributed under the terms of the Creative Commons Attribution-Non Commercial License 4.0 (CCBY-NC), where it is permissible to download, share, remix, transform, and buildup the work provided it is properly cited. The work cannot be used commercially without permission from the journal. 


\title{
يشيشى افكار بار انوئيدى بيمار ان مبتلا به اسكيزوفرنى بر اساس سو كيرىهاى شناختى و خود تأملى
}

\author{
فاضله حيدرى'، سجاد بشريور'، سيف اله آقاجانى" \\ ا.دانشجوى دكترى روانشناسى، گروه روانشناسى، دانشخاه محقق اردبيلى، ادربيل، ايران.
}

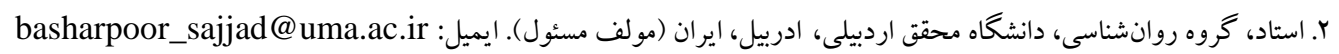

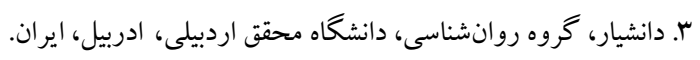

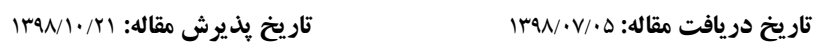

جكيده

مقدمه: افكار بارانوئيد از نشانهاى شايع در اختلالات طيف اسكيزوفرنى است و شواهد از نقش عوامل شناختى در اين افكار حكايت

دارند.

هدف: بُزوهش حاضر با هدف بِيش بينى افكار پِارانوئيدى بيماران مبتلا به اسكيزوفرنى بر اساس سو گيرىهاى شناختى و خودتأملى انجام گرفت.

روش: روش ئزهش حاضر، همبستخى و از نوع بيشبينى است. تمام بيماران مبتلا به اسكيزوفرنى بسترى در بيمارستانهاى

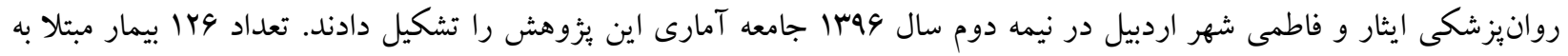

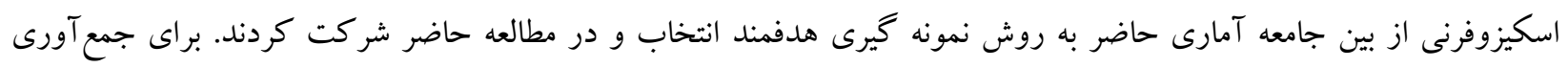

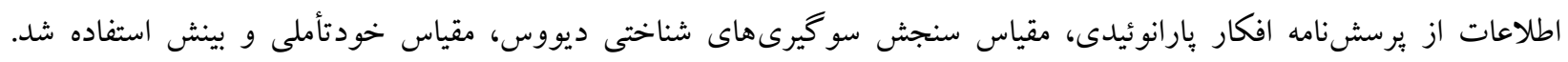

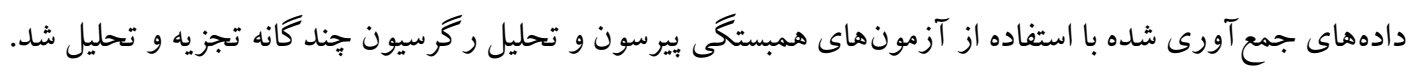
يافتهها: نتايج ضرايب همبستكى نشان داد كه افكار بارانوئيد با سو گيرىهاى نتيجه گيرى شتابزده، انعطافنايذيرى باور، توجه به

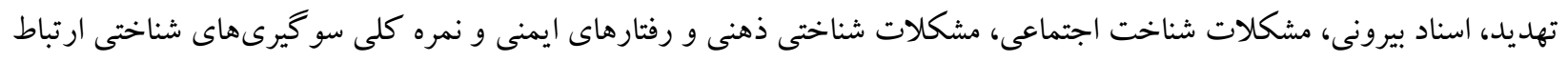

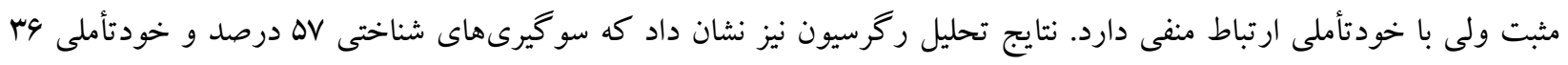

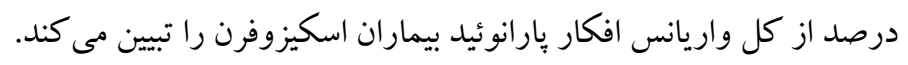

نتيجه كيرى: نتايج مطالعه حاضر نشان مىدهد كه سو گيرىهاى شناختى در تفكر و خودتأملى بايين مىتوانند از عوامل بيشينى

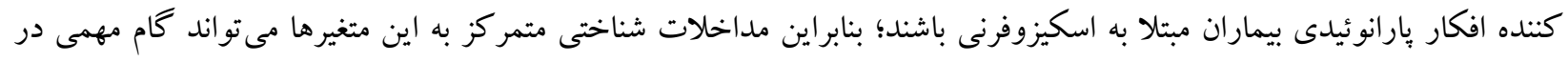
كاهش افكار بارانوئيد اين بيماران باشد.

كليدوازهها: فكر، بارانوئيد، سو گيرى، شناختى، اسكيزوفرنى 


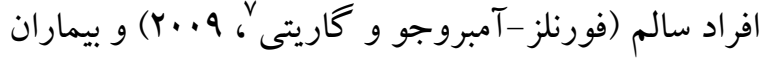
مبتلا به اسكيزوفرنيا (آكرى، سيخرز، است-هيلارى و و

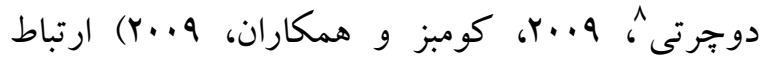

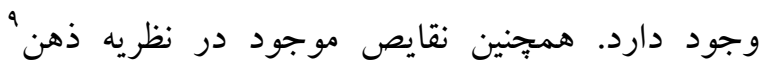
ارتباط معنىدارى با تشديد خيال بِردازى يارانويا دارد

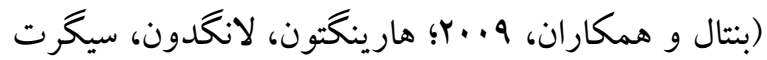

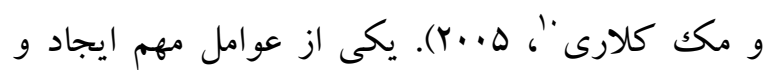

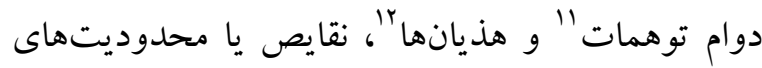

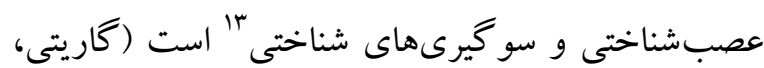

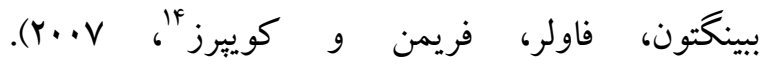
محدوديتهاى عصبشناختى كاهشهاى معنىدارى در ظرفيت توجه كردن، به خاطر سبردن و استدلال است ولى در سو گيرىهاى شناختى ظرفيت بردازش سالم است، در عوض فرايند شناختى انحر اف معنىدارى در قضاوت دارد كه برخى اوقات به تحريف ادراكى و تفسير غيرمنطقى

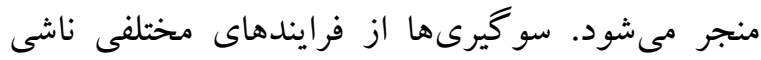
مىشوند كه برخى اوقات تمايز آنها از دشوار است. برخى سو گيرىها بر توجه تأثير مى گذارند؛ برخى ديخر بر تصميم گيرى يا قضاوت از احتمال يا عليت تأثير دارند، در حالى كه برخى نيز بر يادآورى از حافظه يا انخيزش

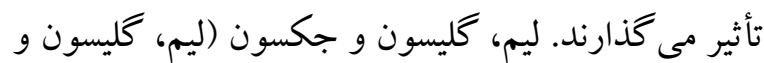

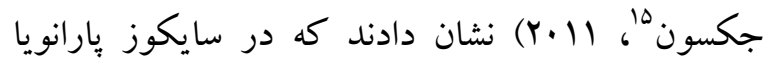
توجه انتخابى به سمت تهديد سو گيرى دارد. نوع ديخرى

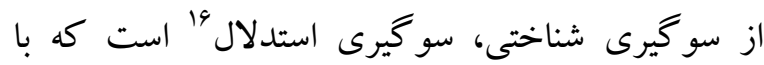
عنوان سو گيرى جمع آورى اطلاعات يا نتيجه گيرىهاى

\footnotetext{
${ }^{7}$. Fornells-Ambrojo M, Garety

${ }^{8}$. Akre, Seghers, St-Hilaire, \& Docherty

9 . Theory of mind

${ }^{10}$. Harrington, Langdon, Siegert, \& McClure

${ }^{11}$. Hallucinations

12. Delusions

${ }^{13}$. Cognitive biases

${ }^{14}$. Garety, Bebbington, Fowler, Freeman, \& Kuipers

${ }^{15}$. Lim, Gleeson, \& Jackson

${ }^{16}$. Reasoning bias
}

\section{مقدمه} بارانويا متداولترين هذيان گزارش شده در افراد داراى تشخيص اختلالات طيف اسكيزوفرنيا است (بنتال و

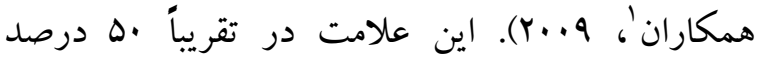
افر ادى كه به دليل يكك اختلال سايكو تيكك جوياى درمان

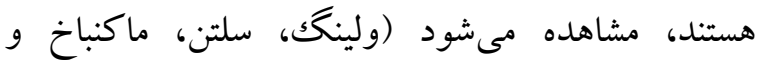

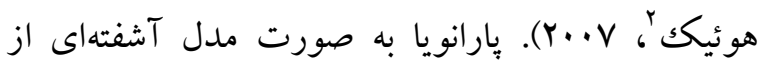
تفكر تعريف شده است كه با بىاعتمادى يا بدكمانى شديد و غيرمنطقى ولى مداوم افراد و تمايل براى تفسير اعمال ديخران به صورت تهديد كننده يا تحقير آميز

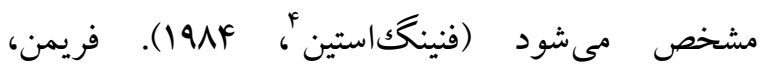
مككمانوس، برو كا، ملتزر، جنگينز و بينگتونه (Y.11) خياليردازى يارانوئيد را در قالب اين باور تعريف كردهاند كه آسيب در حال رخ دادن يا در شرف رخ دادن است. اگرجّه بِرانويا يكى از علائم شايع سايكوز است؛ ولى تفكر يارانوئيد در جامعه عمومى نيز شايع است و تمام بيماران سايكوتيك نيز داراى يارانويا نيستند. شواهد يُزوهشى اخير نشان مىدهد كه ممكن است تفاوتهاى مهمى در روشهاى يردازش اطلاعات بين بيماران اسكيزوفرنى با و بدون افكار بارنوئيد وجود داشته

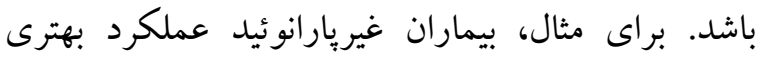
نسبت به بيماران يارانوئيد در بازشناسى هيجانى نشان

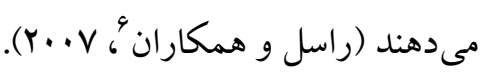
مطالعات زيادى نشان مىدهند كه بين يارانويا و اسنادهاى خصمانه و سرزنش كننده براى رويدادهاى اجتماعى در

\footnotetext{
1 . Bentall et al.

. Veling, Selten, Mackenbach, \& Hoek

3 . Mistrust or suspicion

4. Fenigstein

${ }^{5}$. Freeman, McManus S, Brugha T, Meltzer H, Jenkins R,

Bebbington

${ }^{6}$. Russell et al.
} 


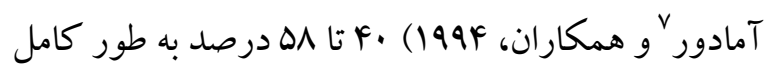
كامل داشتن توهمات و هذيانهاى خود را رد كردند، در اين مطالعه به ترتيب r ب درصد بيماران به طور كامل

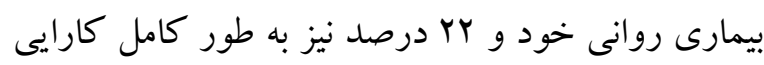
درمان يزشكى خود را رد كردند. اين انكار وجوه مرتبط با بيمارى از نظر بالينى به بينش ضعيف اشاره دارد

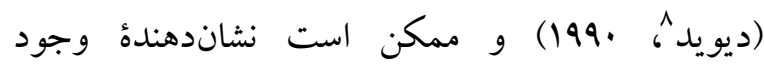
خود آكاهى مختل و و اختلال در خودتأملى باشد. خودتأملى به فرايندهاى هشيار سطح بالايى كفته مى شود كه شامل توانايى شناسايى جنبه هاى مختلف خود از جمله تجربه هيجانى و توصيف آنها در واز كان و كلمات به به تهات صورتى كه قابلفهم باشند. خودتأملى هميجنين شامل توانايى استدلال دربارهُ جنبهايى از خود كه در تعامل با بالي دنيا هستند است. از سوى ديخر، بيمارى كه خودتأملى بالايى داشته و خودآكاهى خصوصى خوبى از بيمارى داشته باشد، باز هم ممكن است انخيزش هشيارانه براى دريغ داشتن اين آكاهى از ديخران (براى مثال، به خاطر

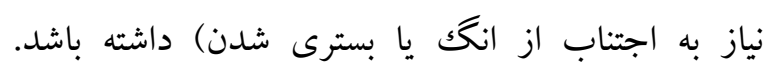

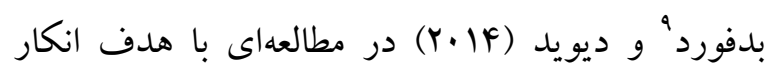

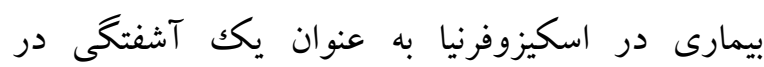

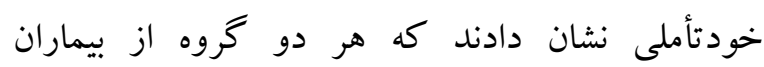
اسكيزفرنيك يذيرنده بيمارى و انكار كنندهُ آن در مقايسه

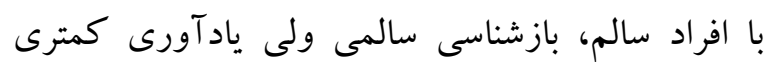

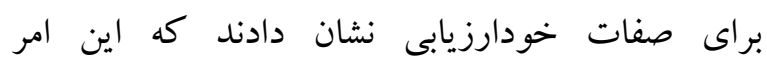
نشاندهنده بردازش سازمانى ضعيف آنها در طول

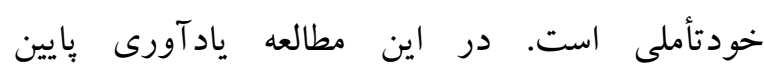
ويزگى هاى بيمارى روانى در خودارزيابى به طور معنىدارى با انكار بالاى بيمارى و شدت بـى بالاى آن همراه

${ }^{7}$. Amador et al.

${ }^{8}$. David

${ }^{9}$. Bedford
شتابزده ' شناخته مىشود و به طور اختصاصى با هذيانها هذيانها ارتباط دارد (ييترز، سورنتون، سيكساو، لينى و

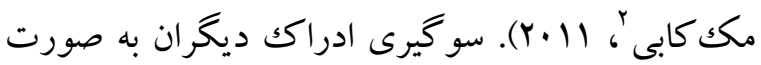
خصمانه و ادر اكك خود به صورت هدف اين خصومت نيز در افراد داراى هذيانهاى گزند و آسيب بَّ وجود دارد

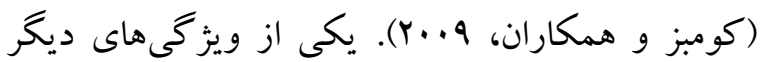
بيماران هذيانى، سو گيرى در برابر شواهد ناهماهنگ است، اين سو گيرى كه سو گيرى انعطافنايذيرى باور ناميده مىشود، مانع ارزيابى مجدد موقعيت ها شده و بيمار رادر عقايد هذيانى گرفتار مىسازد (وودوارد، ميزراهى،

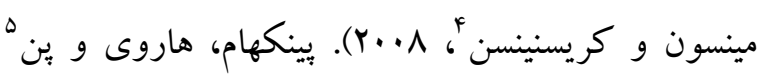

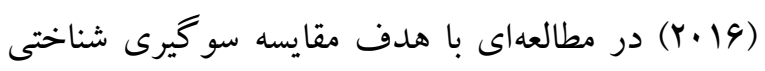
افراد اسكيزوفرنى با بدون هيارانويا بر روى IFV بيمار

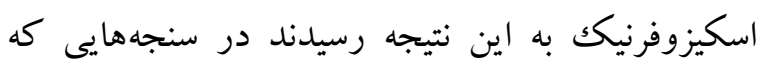
سو گيرى شناختى اجتماعى را ارزيابى مى كنند، افراد يار انويا اسنادهاى خصمانه و سرزنش كننده بيشترى داشتند و اكثر جهرهها را به صورت غيرقابل اعتماد شناسايى كردند. در اين مطالعه، افراد بارانويا در تكاليف بازشناسى هيجان و نظريه ذهن كه توانايى شناختى اجتماعى را ارزيابى مى كرد، تفاوتى با يكديخر نداشتند. در عين حال

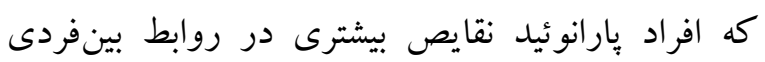
دنياى واقعى و يذيرش اجتماعى در مقايسه با افراد غير بارانوئيد داشتند. ميزان آكاهى و هشيارى بيماران سايكوتيكك از افكار و باورهاى هذيانى، مىتواند تحت تأثير خودتأملى 4 آنها قرار گيرد. از Y I بيمار اسكيزوفرنياى مطالعه شده توسط

\footnotetext{
${ }^{1}$. Jumping to conclusions

2 . Peters, Thornton, Siksou, Linney, MacCabe

${ }^{3}$. Persecutory delusions

4. Woodward, Mizrahi, Menon, \& Christensen

5. Pinkham, Harvey, \&Penn

6. Self-reflection
} 
روش يثزوهش حاضر، همبستخى و از نوع بيشينى بود. تمام بيماران مبتلا به اسكيزوفرنى بسترى در بيمارستانهاى روانيزشكى ايثار و فاطمى شهر اردبيل در نيمه دوم سال

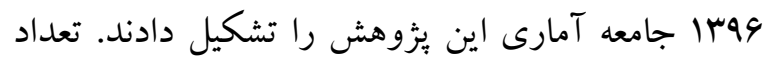
צr ا بيمار مبتلا به اسكيزوفرنى از بين جامعه آمارى حاضر به روش نمونه گيرى هدفمند انتخاب و در مطالعه حاضر

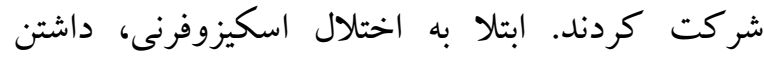
تحصيلات در سطح كلاس هفتم و به بالا از ملاككهاى

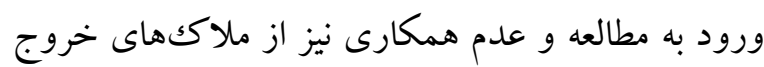
آزمودنىها از مطالعه حاضر بود. از آنجا كه در تحقيقات

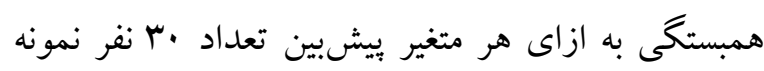
ذكر شده است، در اين مطالعه تعداد •ه نفر نمونه كفايت مى كرد ولى براى افز ايش اعتبار بيرونى مطالعه تعداد • 1r

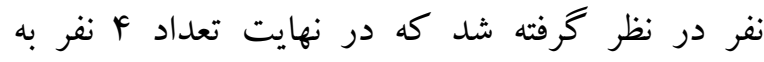

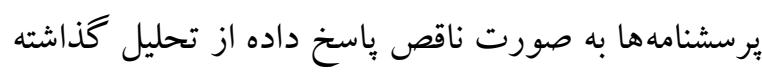

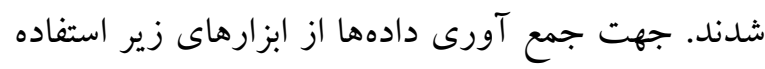

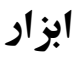
مقياس افكار بإرانوئيد ('G-PTS): ابزارى است كه جهت جهت اندازهيرى صفات و ركههاى تفكر بارانوييد توسط گرين، فريمن، كويرز، بييكتون، فاولر و دان

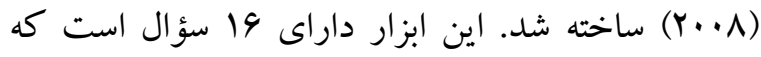

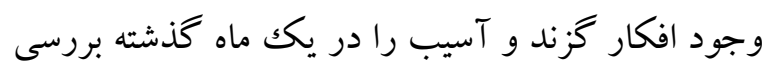
مى كند. هر كدام از سؤالات روى هـ مقياس (هر گز، خيلى كم، تا حدودى، زياد، خيلى زياد) درجهبندى مى آشود. كسب نمره بالاتر از خط برش آزمون، نشاندهنده افكار

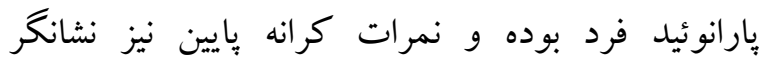

${ }^{2}$. Green et al Paranoid Thought Scales (G-PTS)

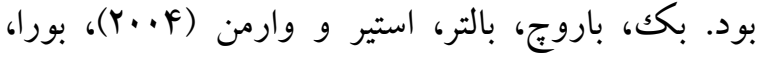

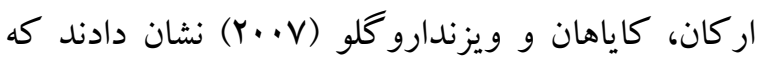
فقدان بينش با علائم سايكو تيكى نظير هذيانها همراه

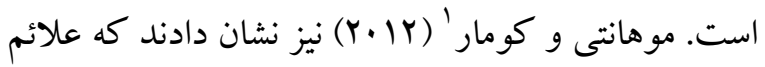
علائم مثبت و منفى در مقياس علائم مثبت و منفى با يقين

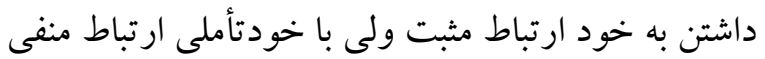
دارد. مرور سوابق موجود نشان مىدهد كه يكى از نارسايىهاى افراد مبتلا به اسكيزوفرنى كه در تعداد زيادى از مطالعات شناخته شده است، سو گيرىهاى شناختى در تفسير محر ككهاى اجتماعى است؛ ولى اين كه كدام نوع از اين ائ

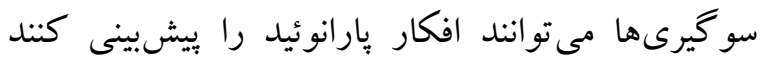
هنوز شناسايى نشده است. همجِين نقايص موجود در خود آكاهى و خودتأملى از ديخر مشخصات شناختى افراد مبتلا به اسكيزوفرنى است، شواهد يُّوهشى نشان مىدهند

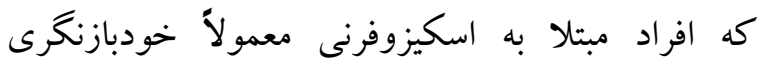
ضعيفى داشته و فاقد تو انايى بازشناسى اعمالى كه انجام دادهاند از اعمالى كه فقط قصد انجام آن را دارند؛ هستند. اين امر نيز مى تواند منجر به آشفتخى شناختى در اين افراد

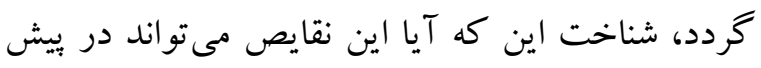
بينى افكار بارانوئيد نقش داشته باشد، هنوز در مطالعات موجود مورد بررسى قرار نخحرفته است؛ بنابراين، با توجه

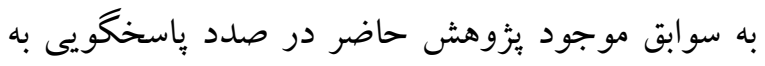
اين سؤال است كه آيا سو گيرى شناختى، حس عامليت و

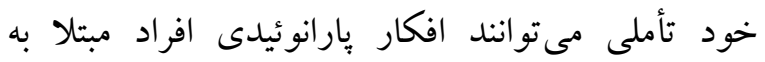
اسكيزوفرنى را ييشينى كنند.

روش 
حاضر از 90/· براى مشكلات شناخت اجتماعى تا 9V/. براى سو گيرى اسناد بيرونى به دست آمد. مقياس خود تأملى و بينش: اين مقياس توسط كرانت،

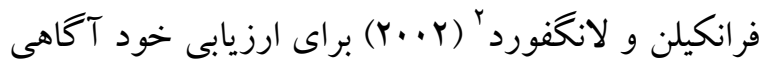
خصوصى كه لازمه هر نوع تغيير رفتارى است ساخته شده است. اين ابزار خود تأملى و بينش را در يكك مقياس ليكرت 9 نقطه ایى از كاملاً مخالفم (1) تا كاملاً موافقم

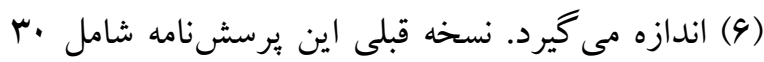

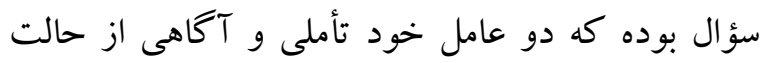
درونى را سنجش مى كرد. در مطالعه تحليل عاملى گرانت

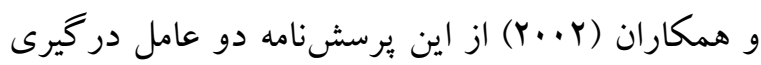
در خودتاملى - نياز به خود تأملى و بينش مشخص شد و

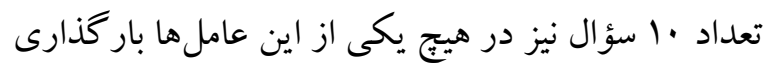

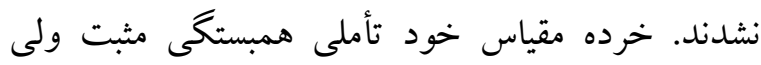
خرده مقياس بينش همبستى منفى با بيرسشنامه خود آكاهى خصوصى نشان داده است. يايايى باز آزمايى اين مقياس در طول V هفته VV/ براى خودتاملى و VA/• براى بينش محاسبه شد. ضريب آلفاى كرونباخ خرده مقياس خود تأملى |9// • و خرده مقياس بينش نيز AV/.

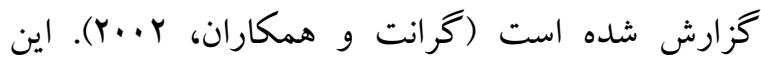

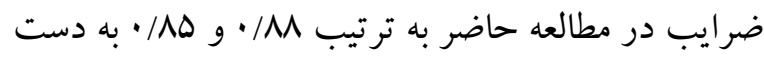

روش جمع آورى دادههاى اين بزوهش به اين صورت بود

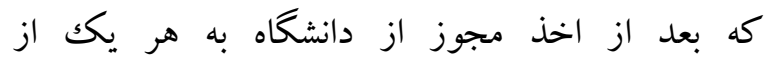

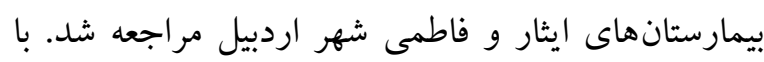
توجه به اينكه بيماران در بخش روان بسترى و به طور متوسط بعد از ها روز ترخيص مىشدند، در فاصله 9 ماهه دوم سال و9با، هر ماه يككبار به بخشهاى مورد نظر
خوشينى فرد نسبت به اطرافيان و محيط است. اين يرسشنامه در بين جمعيت بالينى و غيربالينى، ارزيابى و مشخص شده است از همسانى درونى مناسبى برخوردار

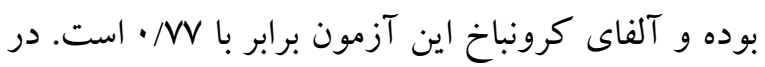

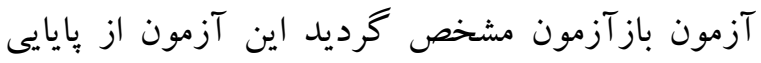

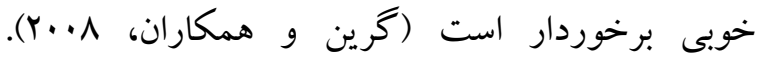
همجنين اين برسشنامه توسط عبدالمحمدى و همكاران در بين جمعيت ايرانى مورد هنجاريابى قرار كرفت كه نتايج به دست آمده براى همسانى درونى، نشان دهنده

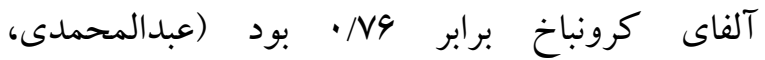
محمدزاده، احمدى و قديرى سورمان، 19 (Y). مقياس سنجش سوكيرىهاى شناختى ديووس: مقياس سنجش سو گيرىهاى شناختى ديووس (DACOBS) يكك ابزار خود گزارشى است كه توسط واندرگيج' و و

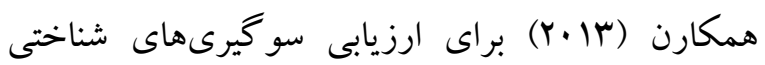
ساخته شده است. اين آزمون شامل بr كويه است كه هر كويه در مقياس ليكزت V نقطهاى از يكك (كاملاً مخالفم)

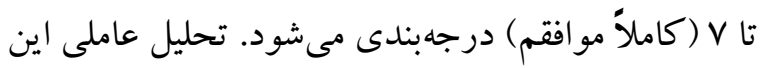
مقياس V عامل نتيجه گيرىهاى شتابزده، سو گيرى انعطافنايذيرى باور، سو گيرى توجه به تهديد، سو گيرى

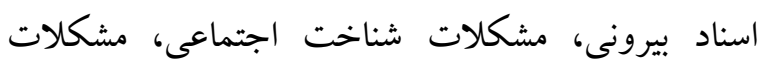
شناختى ذهنى، رفتارهاى ايمنى را آشكار كرد كه در مجموع ها م درصد كل واريانس را تبيين كرد. بايايى اين آزمون نيز خوب به دست آمد (آلفاى كرونباخ=••/9/؛

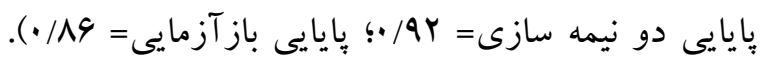
اين مقياس بيماران مبتلا به اختلالات طيف اسكيزوفرنى را از افراد عادى متمايز مىسازد. ضريب آلفاى كرونباخ خرده مقياسهاى اين آزمون در آزمودنىهاى مطالعه

\footnotetext{
1. Van Der Gaag
} 
تنها براى مقاصد يزوهشى مورد استفاده قرار كرفته و به صورت كاملاً محرمانه بوده و به صورت گرورهى مورد مورد تجزيه و تحليل قرار خواهد گرفت. دادههاى جمع آورى

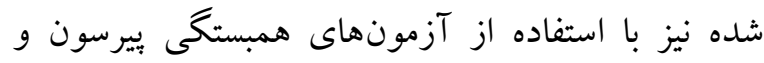
تحليل رگرسيون جند گانه مورد تجزيه و تحليل قرار كرفت.

\section{يافتهها}

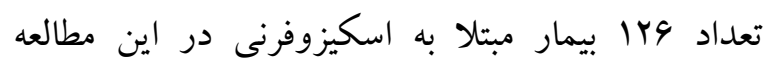
شركت داشتند كه ميانكين (انحراف معيار 士 سن آنها

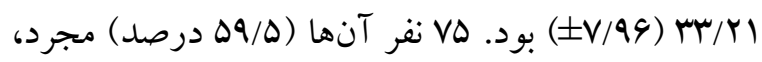
Q و نفر (YN/9 درصد) متأهل، 9 نفر (V/I درصد) متار كه و 4 نفر (F/A درصد نيز مطلقه بودند.
مراجعه و ليست تمامى بيماران مبتلا به اسكيزوفرنى كه با تشخيص روانيزشك در بيمارستان بسترى بودند، در اختيار قرار مى گرفت. سبس نمونه مورد نظر به روش نمونه كيرى هدفمند انتخاب و در مرحله بعد به بيمار در محل بخش مراجعه مىشد. بعد از انجام مصاحبه بالينى ساختار يافته براى تشخيص اسكيزوفرنى بر اساس ملاكك DSM-5 به بيمار تبين و از آنها درخواست شد بهصورت انفرادى به مقياس افكار بارانوئيدى، مقياس سنجش سو گيرىهاى لهـ شناختى ديووس، مقياس خودتأملى و بينش بِاسخ دهند. جهت رعايت ملاحظات اخلاقى تمامى آزمودنىها از آزادى كامل براى مشاركت در بزوهش برخوردار بود و

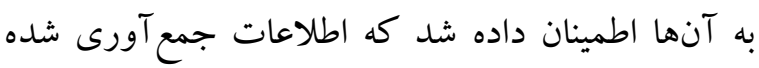

\begin{tabular}{|c|c|c|c|c|c|c|c|c|c|c|}
\hline 9 & $\wedge$ & $\checkmark$ & $q$ & $\Delta$ & $p$ & $r$ & $r$ & 1 & $\begin{array}{c}\text { (انحر اف معيارثين } \\
\text { (انغين }\end{array}$ & متغير ها \\
\hline & & & & & & & & 1 & $\notin \& / 0$. & ا. نتيجه كيرىهاى شتابزده \\
\hline & & & & & & & 1 & $\begin{array}{l}\cdot / \Lambda F^{* * * *} \\
\cdot / \cdots 1\end{array}$ & YF/AG & ז. انعطافنايذيرى \\
\hline & & & & & & 1 & $\begin{array}{l}\cdot / N^{* * *} \\
\cdot / \cdot 1\end{array}$ & $\begin{array}{l}\cdot / M^{* * *} \\
\cdot / \cdot \cdot 1\end{array}$ & $r F / \cdot \wedge$ & r. توجه به تهليد \\
\hline & & & & & 1 & $\begin{array}{l}\cdot / V \Delta^{* * * * *} \\
\cdot / \cdot \cdot 1\end{array}$ & 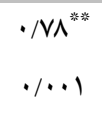 & $\begin{array}{l}\cdot / \Lambda r^{* * * * *} \\
\cdot / \cdots 1\end{array}$ & $r \mid / 91$ & F. اسناد بيرونى \\
\hline & & & & 1 & $\begin{array}{l}\cdot / \mathrm{V}^{* * * *} \\
\cdot / \cdots 1\end{array}$ & $\begin{array}{l}\cdot \mid \wedge 1^{* * * * *} \\
\cdot / \cdots 1\end{array}$ & $\begin{array}{l}\cdot / V r^{* * * * *} \\
\cdot / \cdots 1\end{array}$ & $\begin{array}{l}\cdot / A r^{* * * * *} \\
\cdot / \cdots 1\end{array}$ & rE/Tr & 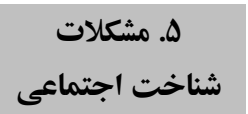 \\
\hline & & & 1 & $\begin{array}{l}\cdot / N^{* * * * *} \\
\cdot / \cdots 1\end{array}$ & $\begin{array}{l}\cdot / Q^{* * * *} \\
\cdot / \cdots 1\end{array}$ & $\begin{array}{l}\cdot / \mathrm{VA}^{\text {******}} \\
\cdot / \cdots 1\end{array}$ & 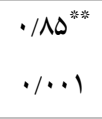 & $\begin{array}{l}\cdot / \Lambda V^{* * * *} \\
\cdot / \cdots 1\end{array}$ & $r \Delta / \cdot 1$ & شناختى ذهكلات \\
\hline & & 1 & $\begin{array}{l}\cdot|\Lambda|^{* * * * *} \\
\cdot / \cdots 1\end{array}$ & $\begin{array}{l}\cdot / r^{* * * *} \\
\cdot / \cdots 1\end{array}$ & $\begin{array}{l}\cdot / V Q^{* * *} \\
\cdot / \cdot 1\end{array}$ & $\begin{array}{l}\cdot / r^{* * * * *} \\
\cdot / \cdots 1\end{array}$ & $\begin{array}{l}\cdot / \mathrm{V}^{* * * * *} \\
\cdot / \cdots 1\end{array}$ & $\begin{array}{l}\cdot / q^{* * * *} \\
\cdot / \cdots 1\end{array}$ & $Y F / Y$. & $\begin{array}{c}\text { Y. رفتارهاى } \\
\text { ايمنى }\end{array}$ \\
\hline & 1 & $\begin{array}{l}\cdot / \Lambda V^{* * * *} \\
\cdot / \cdots 1\end{array}$ & $\begin{array}{l}\cdot / 91^{* * * *} \\
\cdot / \cdots 1\end{array}$ & 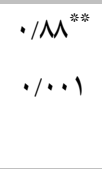 & $\begin{array}{l}\cdot / 19^{* * * * *} \\
\cdot / \cdots 1\end{array}$ & $\begin{array}{l}\cdot / 9 \cdot \cdot^{* * * *} \\
\cdot / \cdot \cdot 1\end{array}$ & $\begin{array}{l}\cdot / 19^{* * * * *} \\
\cdot / \cdots 1\end{array}$ & $\begin{array}{l}\cdot / 9 \Delta^{\text {***** }} \\
\cdot / \cdot 1\end{array}$ & $r D / Y r$ & شو نمره كلى شنى هاخى \\
\hline 1 & $\cdot / \Delta \Lambda^{* * * *}$ & $\cdot / \Delta \Delta^{* * * *}$ & $\cdot / \Delta \Delta^{* * * * * *}$ & $\cdot / \Delta \Lambda^{* * * * * 3}$ & $\cdot 194^{* * * *}$ & $\cdot / A F * * *$ & $\cdot / \mathrm{rq}^{* * * * * *}$ & $\cdot / F \Lambda^{* * * * *}$ & $|V| / F F$ & ج. افكار يارانويا \\
\hline
\end{tabular}




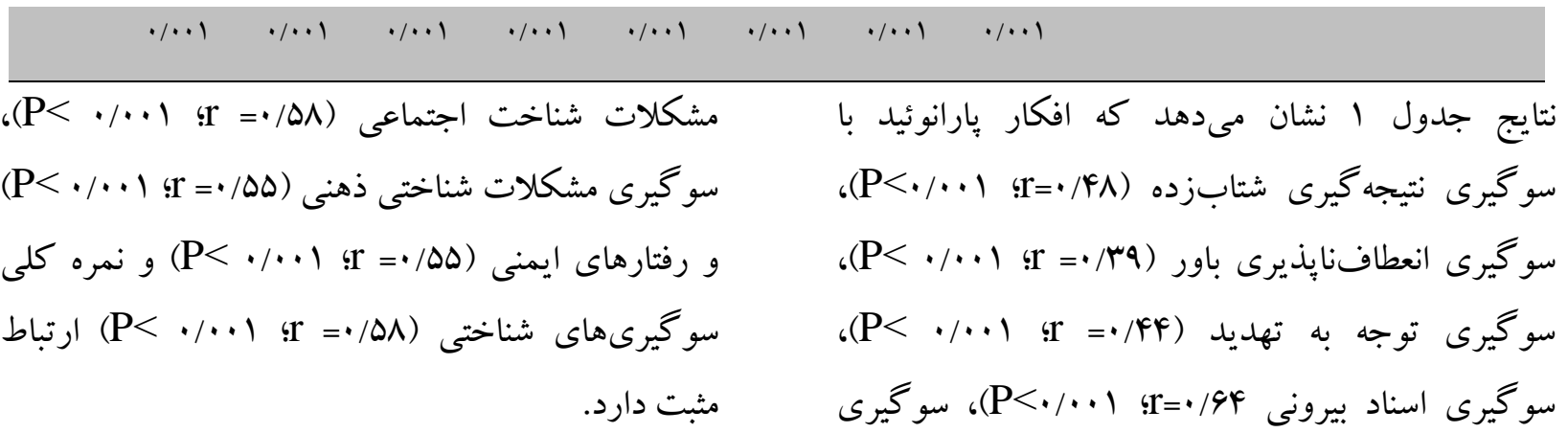

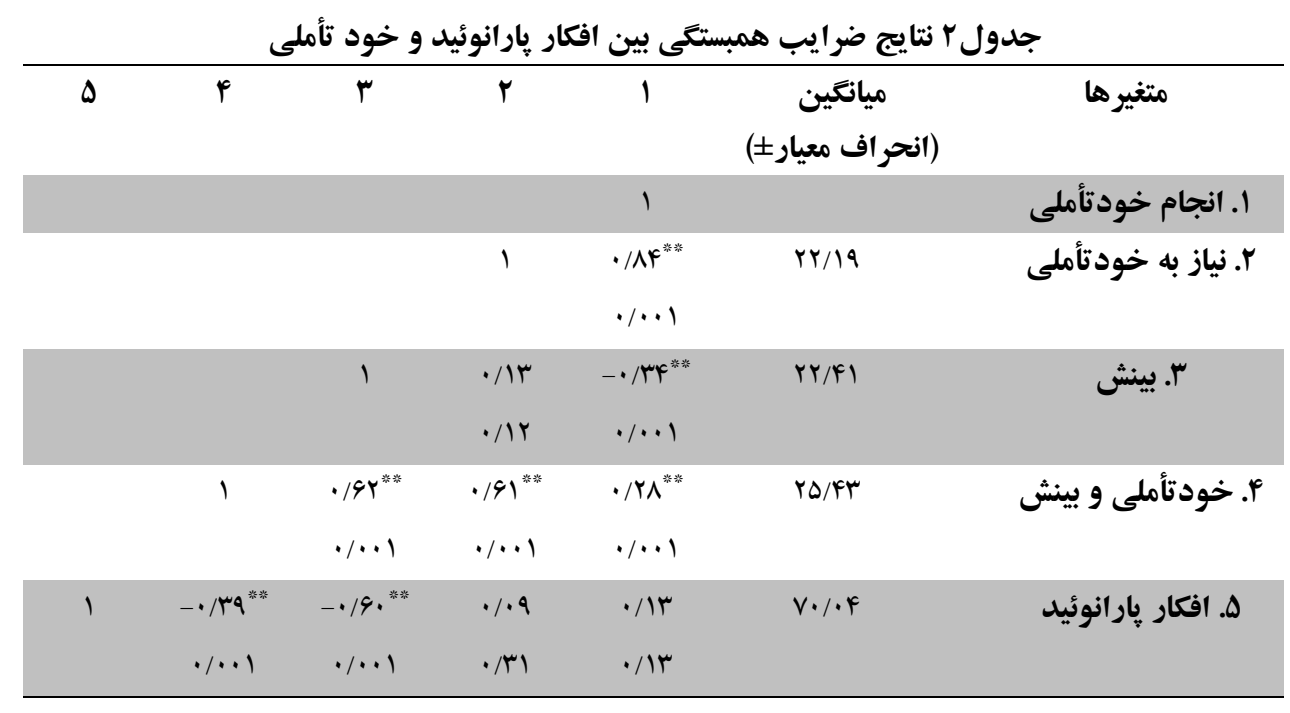

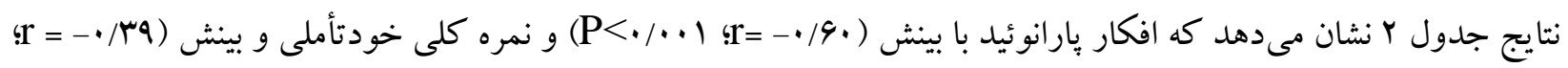
(P< ارتباط منفى دارد.

\begin{tabular}{|c|c|c|c|c|c|c|c|c|c|c|c|}
\hline \multicolumn{2}{|c|}{ آمارههاى هم خطى } & سطح & $\mathbf{t}$ & بتا & خطاى & B & سطح & $\mathbf{F}$ & ضريب & متغير هاى & متغير \\
\hline واريانس & تحمل & معنىدارى & & & $\begin{array}{c}\text { استاندارد } \\
\text { B }\end{array}$ & & $\begin{array}{l}\text { معنى دارى } \\
\text { F }\end{array}$ & & تعيين & ويشيين & ملاكك \\
\hline & & & & & & &.. .1 & rY/AF & $\cdot / \Delta V$ & & \\
\hline & &.. .1 & G/VN & & $r / \uparrow_{A}$ & $r r / 94$ & & & & مقدار ثابت & \\
\hline Q/9Y & $\cdot / 1$ & $.1 . .4$ & r/Ar & $\cdot / \Delta r$ & $\cdot / 4 \Delta$ &.$/ 99$ & & & & نتيجه كيرىهاى & افكار \\
\hline$r / T \Delta$ & $\cdot / \pi$ &.$/ .1$ & $r / a r$ & $\cdot / 49$ & $\cdot / r \Delta$ & 1 & & & & انعطافنايذيرى & هِارانوئيد \\
\hline$\Delta / r F$ &.$/ 19$ & $\cdot / 49$ & $-1 / 1 r$ &.$- / 10$ & $\cdot / r 9$ & $-\pi / T$ & & & & توجه به تهايد & \\
\hline$r / 9 r$ & $\cdot / r \Delta$ & $\cdot / . \cdot 1$ & $\Delta / q V$ & $\cdot 190$ & $\cdot / r$. & $1 / 1 r$ & & & & اسناد بيرونى & \\
\hline$r / v r$ & $\cdot / 49$ &.$/ .1$ & $F / Y q$ & $\cdot / 49$ & $\cdot / 11$ & $\cdot / \mathrm{VA}$ & & & & مشكلات & \\
\hline
\end{tabular}




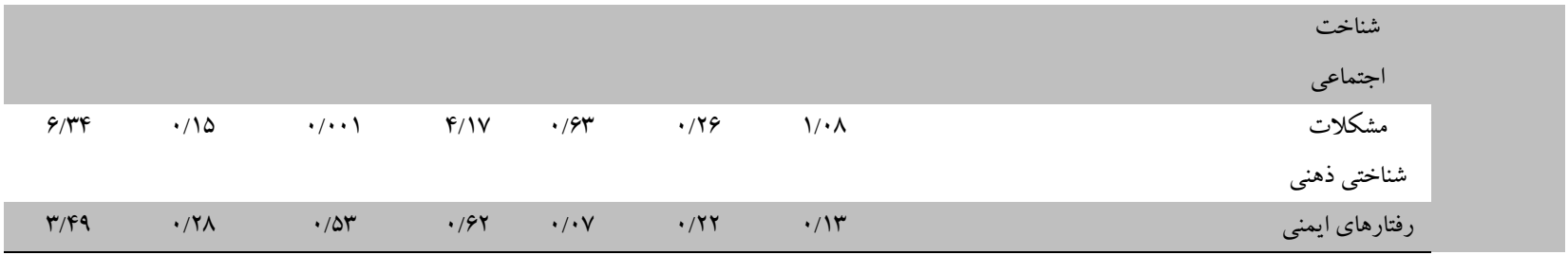

تصادفى بيش آمده باشد. مدل مورد نظر نيز از لحاظ آمارى معنادار است. نتايج ضرايب رگرسيون نيز نشان

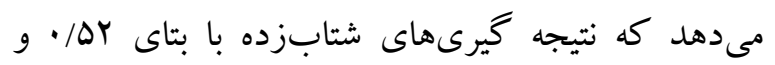

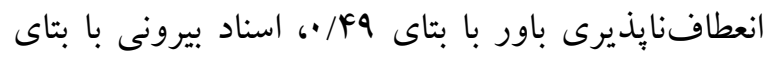

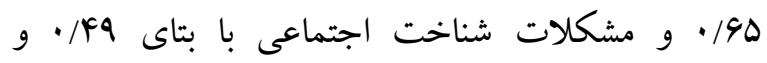

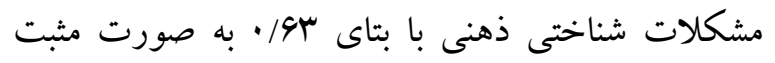
افكار بِار انوئيد را ييش بينى مى كنند.
جدول r نشان مىدهد كه در حدود OV درصد از كل

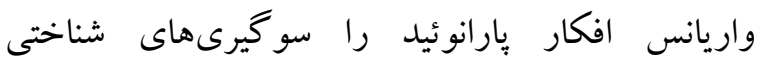
ييشبينى مى كند. نتايج آزمون تحليل واريانس (مقدار F) هم نشان مىدهد كه رگرسيون افكار يارانوئيد بر اساس سو گيرىهاى شناختى معنادار است؛ يعنى رابطة بين افكار بارانوئيد و يكك تركيب خطى مبتنى بر كمترين مجذورات از هفت سو گيرى شناختى احتمالاً نمى تواند

\begin{tabular}{|c|c|c|c|c|c|c|c|c|c|c|c|}
\hline \multicolumn{2}{|c|}{ آمارههاى هم خطى } & \multirow{2}{*}{ معنى سطحى } & \multirow[t]{2}{*}{$\mathrm{t}$} & \multirow[t]{2}{*}{ بتا } & \multirow{2}{*}{$\begin{array}{c}\text { خ استارداى } \\
\text { B }\end{array}$} & \multirow[t]{2}{*}{ B } & \multirow{2}{*}{$\begin{array}{c}\text { معنى } 1 \text { سطىى } \\
\text { F }\end{array}$} & \multirow[t]{2}{*}{$\mathbf{F}$} & \multirow{2}{*}{ ضريب } & \multirow{2}{*}{ متيشيرهاى } & \multirow{2}{*}{ ملاكى متير } \\
\hline واريانس & تحمل & & & & & & & & & & \\
\hline & & & & & & & $\cdot / \cdot .1$ & TY/QT &.$/ 49$ & & \\
\hline & &.$/ .1$ & $9 / 99$ & & N/Y9 & $\mathrm{Va} / \mathrm{Al}$ & & & & مقدار ثابت & افكار \\
\hline $1 / r$ & $\cdot / A r$ & $\cdot / 49$ & $-1 / 1 r$ & $-\cdot / \cdot \Lambda$ & $\cdot / \Gamma \Lambda$ & $-\cdot / \Gamma /$ & & & & خودتأملى & يِراتويد \\
\hline $1 / \cdot 1$ & . /9Y & $\cdot N$ & . &.$/ \%$ & $\cdot / \mathrm{VV}$ & .1 .9 & & & & خو نياز به & \\
\hline $1 / 14$ & $\cdot / M$ &.$/ .1$ & $-\Lambda / r \Delta$ &.$- / 94$ & ./r & $-1 / \cdot 9$ & & & & بينش & \\
\hline
\end{tabular}

مقدار بتاى سو/ •- بهصورت منفى افكار پيارانوئيد را بيش

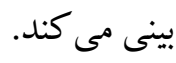

بحث

افكار بارانوييد از جمله مشخصههاى اختلالات روانيريشى و برخى اختلالات شخصيتى است كه باعث

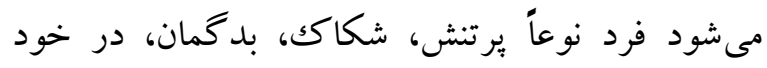
فرورفته و كاه متخاصم يا برخاشخر شود. با توجه به مبانى
جدول F نشان مىدهد كه در حدود 4M درصد از كل واريانس افكار يارانوئيد را خود تأملى بيشبينى مى كند. نسبتF هم نشان مىدهد كه رگرسيون افكار بِارانوئيد بر اساس خود تأملى معنادار است؛ يعنى رابطة بين افكار يارانوئيد و يكك تر كيب خطى مبتنى بر كم ترين مجذورات

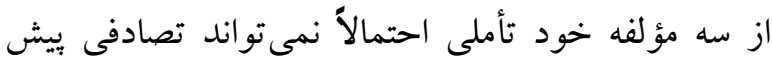
آمده باشد. مدل مورد نظر نيز از لحاظ آمارى معنادار است. نتايج ضرايب رگرسيون نيز نشان مىدهد كه بينش با بـ 
بيرونى به صورت تهلديد كننده ادراكك شوند. نتايج تحليل ركرسيون نيز نشان داد كه نتيجه گيرىهاى شتابزده و انعطافنايذيرى باور، اسناد بيرونى، مشكلات شناخت اجتماعى و مشكلات شناخت ذهنى به صورت مثبت افكار يارانوئيد را بيشبينى مى كنند. اين نتايج نيز با نتايج

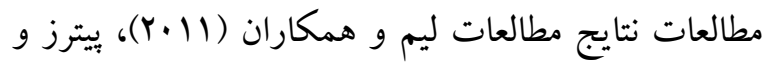

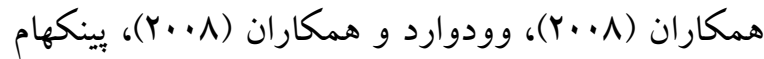
و همكاران (19) و و فورنيلز-آمبروجو و و كاريتى

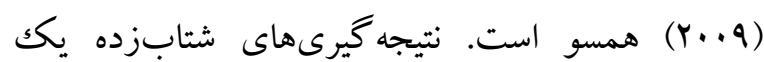
سو گيرى سنخ بديدارى درونى باست، به اين معنا كه اين

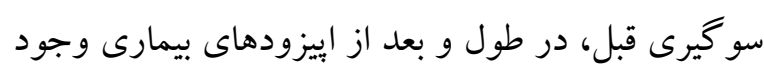
دارد و معمولاً والدين و همشيرهاى بيماران اين سو گيرى را به ميزان بيشترى در مقايسه با جمعيت عمومى نشان مىدهند (وانديال، ويرسميسن، جانسين، ميين-گرميير و

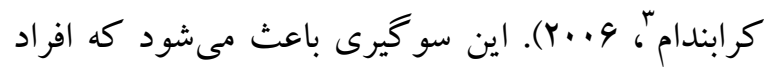
ديخر به صورت خصمانه، ادراكك شوند و خود شخص نيز به عنوان نقطه هدف خصومت ديخران در نظر گرفته شود

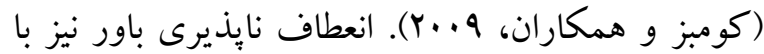
سو گيرى در برابر شواهد مخالف مشخص مىشود اين سو گيرى مىتواند با ايجاد محدوديت در ارزيابى مجدد موقعيت هاى افكار يارانويا را افزايش دهد. اسناد بيرونى از جمله سو گيرىهاى شناختى است كه با سلب مسئوليت فرد از اعمال و رويدادها مىتواند زمينهاى براى دفاعهاى يارانويا باشد. در نهايت مشكلات شناخت اجتماعى و شناخت ذهنى نيز دو محدوديت شناختى هستند كه مى توانند منجر به بر آورد كمتر از حد تو انايىهاى شناختى شده و در شكست اجتماعى و كناره گيرى اجتماعى نقش داشته باشند. در صورتى كه بيمار از نقايص، رويكردهاى سلى

${ }^{2}$. Endophenotypical

${ }^{3}$. Van Dael, Versmissen, Janssen, Myin-Germeys, van Os, \& Krabbendam
شناختى اين افكار، يُزوهش حاضر با هدف تعيين نقش سو گيرىهاى شناختى و خودتأملى در بيشينى افكار يار انوئيدى افراد مبتلا به اسكيزوفرنى انجام كرفت. نتايج به دست آمده نشان داد كه افكار پِارانوئيد با بادئ سو گيرى نتيجه گيرى شتابزده، سو گيرى انعطافنايذيرى باور، سو گيرى توجه به تهديد، سو گيرى اسناد بيرونى، سو گيرى مشكلات شناخت اجتماعى، سو گيرى مشكلات شناخت ذهنى، رفتارهاى ايمنى و نمره كلى سو گيرىهاى شناختى ارتباط مثبت دارد. اين نتايج با نتايج مطالعات ليم

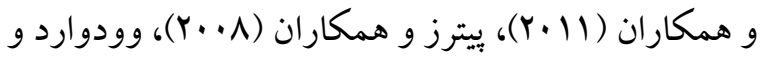

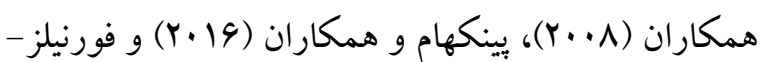

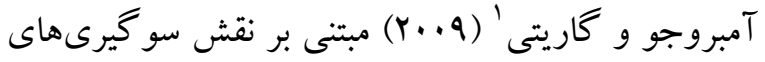
شناختى در هذيانهاى بِارانوياى بيماران اسكيزوفرن همسو است. سو گيرى نتيجه گيرى شتابزده كه سو گيرى لئى استدلال نيز ناميده مىشود، مانع جمع آورى اطاعات لازم قبل از نتيجه گيرى مى شود. سو گيرى انعطاف نايذيرى باور نيز مانع ارزيابى مجدد موقعيتها شده و بيمار را در عقايد هذيانى گرفتار مىسازد. سو گيرى توجه به تهديد نيز باعث مى شود، توجه انتخابى فرد به صورت يك آمادگى از ييش موجود به سمت تهديدهاى بالقوه گرايش بيدا

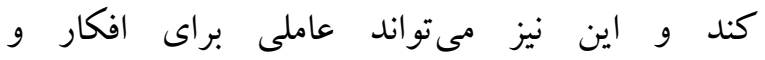
خياليردازىهاى بارانويا شود. سو گيرى اسناد بيرونى نيز

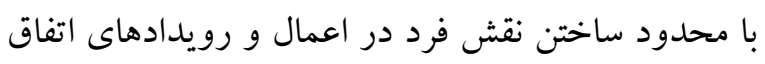
افتاده، علت ناملايمات به وجود آمده را به بيرون فرافكنى كرده و زمينه را براى بدگمانى و بىاعتمادى نسبت به محيط افزايش مىدهد. مشكلات شناخت اجتماعى و شناخت ذهنى نيز از جمله سو گيرىهاى مرتبط با نقص در يادآورى اطلاعات هستند كه باعث مىشوند رويدادهاى

\footnotetext{
${ }^{1}$. Fornells-Ambrojo, \& Garety
} 
مىدهند كه اين امر نيز به كاهش افكار بدبينانه و بارانويا و در نهايت به بهبود كيفيت زندگى بهتر بيماران منجر مىشود. همجنين در صورتى كه بيمار اسكيزوفرن قادر به تأمل و تعمق درباره علائم خود باشد، به صورت بهترى مى تواند از ماهيت غيرواقعى تجربه هاى خود بينش كسب كرده و به صورت بهترى قادر به ساز كارى با واقعيت هاى زندگى باشد.

\section{نتيجه كيرى}

در كل نتايج مطالعه حاضر نشان داد كه سو گيرىهاى

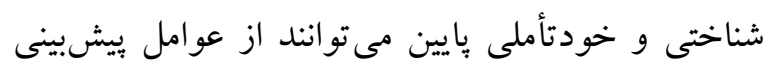
كنده افكار يارانوييدى بيماران اسكيزوفرن باشند. وجود

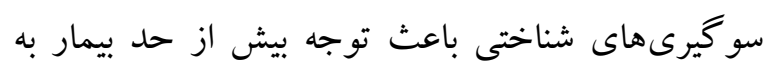

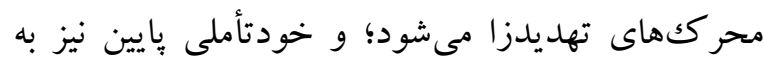

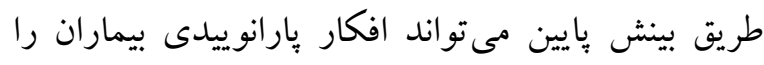

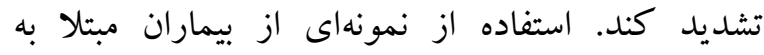
اسكيزوفرنى بسترى در بيمارستان، ناتوانى در كنترل برخى متغيرهاى مزاحم بالينى نظير استفاده از داروهاى متفاوت، طول دوره بيمارى، تظاهرات متفاوت بالينى و منحصر بودن مطالعه حاضر به نمونهاى از بيماران مذكر مبتلا به اسكيزوفرنى محدوديتهاى مطالعه حاضر بود؛ بنابراين ييشنهاد مىشود در مطالعات آتى براى تعميم بيشتر يافتها، علاوه بر بيماران بسترى، از بيماران سريايى هر و دو جنس زن و مرد نمونه گيرى شود و متغيرهاى مزاحم استفاده از داروهاى، طول دوره بيمارى، تظاهرات بالينى كنترل شوند. نتايج مطالعه طر احى مداخلات درمانى مبتنى بر اصلاح سو گيرىهاى شناختى و تقويت خودتأملى در كاهش افكار پيارانوييدى بيماران اسكيزوفرن را بيشنهاد

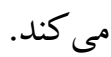

آموزش و درمانى كه جبران كننده تأثير نقايص شناختى در زندكى روزمره هستند، آكاهى نداشته باشد، بيشتر خيال بردازى بارانويا خو اهد داشت.

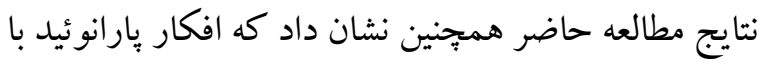
بينش و نمره كلى خودتأملى ارتباط منفى دارد. اين نتايج

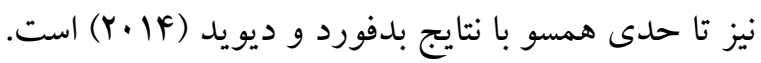
خودتأملى به فرايندهاى آكاهانهُ سطح بالايى كَّته مىشود كه شامل شناخت جنبهايى از خود نظير تجربه هيجانى و توصيف آنها در كلمات و توانايى استدلال درباره جنبههايى از خود كه با محيط در تعامل هستند، است. خودتأمل بودن باعث مىشود فرد عقايدى درباره درونى ترين افكار، احساسات و انخيزههايش داشته باشد و خودش را به عنوان عامل فعالى در محيط اجتماعى بيند كه عملكرد مؤثرى دارد. افرادى كه خودتأملى يايينى دارند، به ميز ان بيشترى به مكانيسم دفاعى فر افكنى متوسل مى شوند، اين امر نيز مىتواند به تشديد افكار يارانويا منجر شود. نتايج تحليل رگرسيون نيز نشان داد كه از بين سه مؤلفه خودتأملى، فقط بينش بهصورت منفى افكار

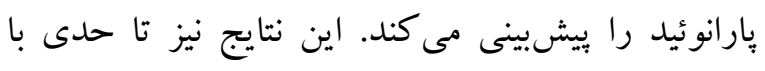

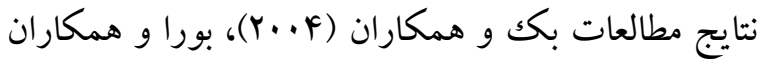
(Y.VV) جون هذيانها همسو است. بيمارانى كه بينش بالايى دارند، از نظر عقلانى انعطاف نايذيرى كمترى دارند و به تبيين هاى جايكزين و فرعى براى تجربه هاى خود كشوده تر هستند كه اين امر مى تواند با تفكرات هذيانى

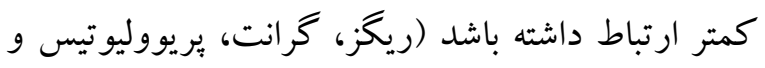
بكك'، Y Y.Y.). از طرف ديخر بيمارانى كه خودتأملى و بينش بالايى دارند، تعاملات اجتماعى بهترى نشان 
depression. Archiews of General Psychiatry, 66(3), 236-247.

Bora E, Erkan A, Kayahan B, \& Veznedaroglu B. (2007). Cognitive insight and acute psychosis in schizophrenia. Psychiatry \& Clinical Neuroscience, 61(6), 634-649.

Combs DR, Penn D, Michael CO, Basso MR, Wiedeman R, Siebenmorgan M, Tiegreen J, \& Chapman D. (2009). Perceptions of hostility by persons with and without persecutory delusions. Cognitive Neuropsychiatry, 14(1), 30-52.

David AS. (1990). Insight and psychosis. British Joumal of Psychiatry, 156 (6), 798-808.

Fenigstein A. (1984). Self-consciousness and the overperception of self as target. Journal of Personality and Social Psychology, 47 (4), 860-870.

Fomells-Ambrojo M, \& Garety PA. (2009). Attributional biases in paranoia: the development and validation of the Achievement and Relationships Attributions Task (ARAT). Cognitive Neuropsychiatry, 14 (2): 87-109.

Fomells-Ambrojo M, Garety PA. (2009). Attributional biases in paranoia: the development and validation of the Achievement and Relationships Attributions Task (ARAT). Cognitive Neuropsychiatry, 14(2), 87-109.

Freeman D, McManus S, Brugha T, Meltzer H, Jenkins R, Bebbington P. (2011). Concomitants of paranoia in the general population. Psychological Medicine, 41(5), 923-936.

Garety PA, Bebbington P, Fowler D, Freeman D, \& Kuipers E. (2007). Implications for neurobiological research of cognitive models of psychosis: a theoretical paper. Psychological Medicine, 37 (10), 1377-1391.

Grant AM, Franklin J, \& Langford P. (2002). The SelfReflection and Insight Scale: A new measure of private self-consciousness. Social Behavior and Personality, 30, 821-836.

Green C, Freeman D, Kuipers E, Bebbington P, Fowler D, \& Dunn G. (2008). Measuring ideas of persecution and reference: the Green et al

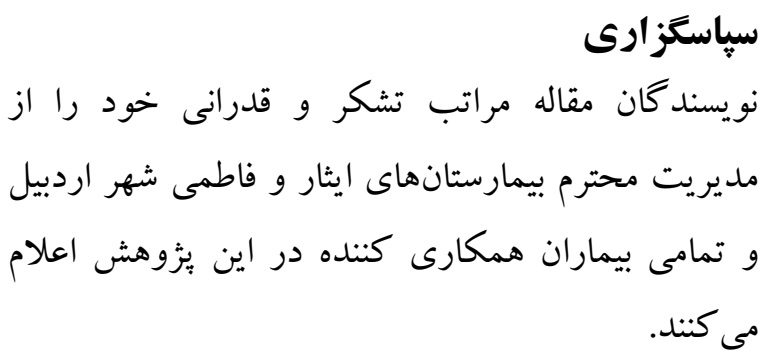

\section{References}

Aakre JM, Seghers JP, St-Hilaire A, Docherty N. (2009). Attributional style in delusional patients: a comparison of remitted paranoid, remitted nonparanoid, and current paranoid patients with nonpsychiatric controls. Schizophrenia Bulletin, 35(5), 994-1002.

Abdolmohammadi K, Mohammadzadeh A, Ahmadi E, \& GhadiriSourman F. (2016). Validation of the Paranoid Thoughts Scale in Iranian Population. Qom University of Medical Science Journal, 10(8), 47-53.

Amador XF, Flaum M, Andreasen NC, Strauss DH, Yale SA, Clark SC, \& Gorman JM. (1994). Awareness of illness in schizophrenia and schizoaffective and mood disorders. Archives of Genenal Psychiatry, 51, 826-836.

Beck AT, Baruch E, Balter JM, Steer RA, \& Warman DM. (2004). A new instrument for measuring insight: the Beck Cognitive Insight Scale. Schizophrenia Research, 68, 319-329.

Bedford NJ, \& David AS. (2014). Denial. of illness in schizophrenia as a disturbance of selfreflection, self-perception and insight. Schizophrenia Research, 152, 89-96.

Bentall RP, Rowse G, Shryane N, Kinderman P, Howard R, Blackwood N, Moore R, Corcoran R. (2009). The cognitive and affective structure of paranoid delusions: a transdiagnostic investigation of patients with schizophrenia spectrum disorders and

Paranoid Thought Scales (G-PTS). Psychological Medicine, 38, 101-111. 
Harrington L, Langdon R, Siegett RJ, \& MoClure J. (2005). Schizophrenia, theory of mind, and persecutory delusions. Cognitive Neuropsychiatry, 10(2), 87-104.

Lim M, Gleeson JF, \& Jackson HJ. (2011). Selective attention to threat bias in delusion prone individuals. Joumal of Nervous and Mental Disorders, 199 (10), 765-772.

Mohanty S, \& Kumar S. (2012). Psychopathology and Cognitive Insight in Patients with Chronic Schizophrenia. Indian Journal of Clinical Psychology, 39, 124-127.

Peters ER, Thornton P, Siksou L, Linney Y, \& MacCabe JH. (2008). Specificity of the "jumpto-conclusions' bias in deluded patients. British Journal of Clinical Psychology, 47, 239-244.

Pinkham A, Harvey EPD, \& Penn DL. (2016). Paranoid individuals with schizophrenia show greater social cognitive bias and worse social functioning than non-paranoid individuals with schizophrenia. Schizophrenia Research: Cognition, 3:33-38.

Riggs SE, Grant PM, Perivoliotis D, \& Beck AT. (2012). Assessment of Cognitive Insight: Qualitative Review. Schizophrenia Bulletin, 38(2), 338-350.

Russell TA, ReynaudE, Kucharska-Pietura K, EckerC, Benson PJ,Zelaya F, Giampietro V, Brammer M, David A, Phillips ML. (2007). Neural responses to dynamic expressions of fear in schizophrenia. Neuropsychological, 45(1), 107-123.

VanDael F, Versmissen D, Janssen I, Myin-Germeys I, Van Os J, \& Krabbendam L. (2006). Data gathering: biased in psychosis? Schizophrenia Bullition, 32(2), 341-351.

VanDerGaag M, Schutz C, TenNapel A, Landa Y, Delespaul P, Bak M. (2013). Development of the Davos Assessment of Cognitive Biases Scale (DACOBS). Schizophrenia Research, 144(1-3), 63-71.

Veling W, Selten JP, Mackenbach JP, Hoek HW. (2007). Symptoms at first contact for psychotic disorder. comparison between native Dutch and ethnic minorities. Schizophrenia Research, 95(1-3), 30-38.
Woodward TS, Mizrahi R, Menon M, \& Christensen BK. (2008). Comespondences between theory of mind, jumping to conclusions, neuropsychological measures and the symptoms of schizophrenia. Psychiatry Research, 170,119-123. 